Therexsys hopes to develop an approach to gene therapy in which genes are accurately targeted and regulated. The technology could be applicable to both acute and, eventually, chronic therapy in a number of disease areas, including cancer, cardiovascular disease and the treatment of inflammation.

No details have been released of the precise techniques under development, partly because the company is still in the process of applying for some of the important patents. But they are thought to involve ways of inserting genes into cells using the ability of ligands such as monoclonal antibodies to target tumour and other diseased cells.

The MRC's contribution is based on research on the regulation of gene expression at NIMR by a team led by Frank Grosveld, head of the institute's laboratory of gene structure and expression. Therexsys will have an exclusive licence to the intellectual property, both existing and in future, arising from this work.

The practical application of the techniques will be explored by a research group headed by Mike Dexter, head of the department of experimental haematology at the Paterson Institute of Cancer Research in Manchester. Dexter is widely known for his work on the biology of the stem cells that give rise to blood cell lineages and for his interest in blood-borne tumours, which could be particularly susceptible to the ligandmediated insertion of genes.

Craig has strong links to both the MRC and the CRC. While still at ICI, he belonged to a number of the research council's committees, including its neurosciences committee, its genetics policy group, and the directed programme committee of the Human Genome Mapping Project. He is also a member of the governing committee of the Paterson Institute.

MRC's past efforts to encourage technology transfer from its laboratories have been based primarily on negotiating licencing deals for work from its laboratories, and receiving income through the resulting royalty payments. That was the model for the biotechnology company Celltech, established with government help in 1980. But the company has yet to make a profit, and the return to the MRC so far has been disappointing.

Dai Rees, the secretary of the council, says that the MRC "has now realized the advantage of a mechanism which does not involve royalty deals, but in which we put in the knowledge, taking an equity stake in retum, and other [investors] put in their capital".

The council already has a small equity stake in Cambridge Antibodies, based on work on antibody engineering at its Laboratory for Molecular Biology in Cambridge, and a similar stake in Somatogen, Inc, which works on artificial blood products. In contrast, an equity stake is a new idea for CRC Technology, which plans to return any profits to the CRC through covenants.

David Dickson

\title{
Congress asks universities to justify special funding
}

Boston. The chairman of the science committee in the US House of Representatives hopes to use US research universities as a wedge for reclaiming political power.

Representative George Brown (Democrat, California) has begun a study of the growing congressional practice of "earmarking' federal dollars for large academic research facilities that have been neither requested by the relevant federal agency nor debated and judged worthy by the entire Congress. Last week Brown mailed a letter to 50 universities that received as much as $\$ 10$ million last year for such projects, asking them to explain themselves.

Brown has fought the growing practice (\$773 million was allocated to some 500 projects last year, triple the amount spend in 1990 ) on the grounds that it subverts the normal process of scientific review and because "it comes out of the hide of existing programs". But he admits that his campaign against so-called academic pork-barrel projects is also part of an effort to reestablish the importance of authorization committees such as his.

"The regular order of Congress requires universities to submit their projects to the appropriate agency and then to have that agency obtain an authorization to do what it wants", Brown explained last week during a press conference at the annual meeting of the American Association for the Advancement of Science (AAAS) in Boston. "Only

\section{Massey says that NSF must tighten its belt}

Washington. The National Science Foundation (NSF) must figure out a way to do its jobdespite insufficient resources, acccording to outgoing director Walter Massey.

Speaking last week with uncharacteristic frankness to a meeting of the National Science Board, NSF's governing body, Massey said that NSF staff must simplify the grantmaking process and lighten its workload because "we aren't going to get the additional resources we need". That concession brings down the curtain on a promise made by presidents Ronald Reagan and George Bush to double the NSF budget within five years and could be a harbinger of the foundation's budget for next year, which will be released on 23 March.

Massey described for the science board the process that he began a year ago to develop a long-range strategy for the foundation. Although work on the strategy is still under way and may never be made into a public document, Massey said that he has asked senior NSF officials by May to draw up details of how to then should they turn to the appropriations process to get the money they need."

"Certain powerful members of Congress", Brown adds, have distorted that process by ignoring the authorizing committees and winning approval for pet projects at the final stage of the legislative process, when committees from each house meet to iron out the details of spending bills. The full Congress rarely has time to scrutinize the work of such conference committees.

For example, Senator Bennett Johnston (Democrat, Louisiana), is chairman of both the authorizing committee for the Department of Energy (DOE) and the appropriations subcommittee that funds it. The dual positions make it possible for Johnston to get money for certain projects without first having the money authorized, a luxury not afforded Brown and most other members of Congress. Perhaps not coincidentally, the energy and water appropriations bill is each year also loaded with such earmarks for universities.

Brown's questionnaire asks universities to describe the type of review their project has undergone and whether they sought approval from any federal agency before approaching Congress. University officials in the past have justified such projects by saying that there is no federal programme to repair and renovate academic research facilities and, thus, no alternative way to obtain such badly needed funds. Jeffrey Mervis

implement it in five critical areas.

"We have to lower the barriers to interdisciplinary work", he said, "and we have to extend our resources by working more closely with other agencies. We need to better integrate education into each of the research directorates, and we need to do business differently to account for the fact that there is no realistic chance our [staff] budget will grow significantly."

The science board decided to spend a good deal of time in the next several months in discussing ways to implement the recommendations of the report last autumn by the Commission on the Future of NSF (Nature 360, 285; 1992). Although it would not be the first time that the science board has sought to play a larger role in defining US science and technology policy, board members believe that their chances of success have improved as a result of several recent reports on the subject and a greater receptiveness to such thinking by the new administration.

Jeffrey Mervis 